\section{Altered Cell Walls of Staphylococcus aureus resistant to Methicillin}

METHICILLIN-resistant (MR) strains of Staphylococcus aureus, those capable of multiplying in the presence of $12.5 \mu \mathrm{g}$ of methicillin $/ \mathrm{ml}$. (eight or more times that tolerated by methicillin-sensitive (MS) strains), are also resistant to other commonly used antibioties, including other semi-synthetic ponicillins and cephalosporins ${ }^{1-?}$. They can cause major disease ${ }^{6-11}$ and thus may pose a scrious therapeutic problem.

The mechanism of resistance to methicillin seems to be independent of penicillinase ( $\beta$-lactamase) because MR strains grow in the presence of high concentrations of methicillin 7,12 , and because variants which have lost the ability to synthesize penicillinase remain $\mathrm{MR}^{10,13}$. Thus the mechanism is grossly different from that by which most strains of $S$. aureus resist benzylpenicillin-by means of penicillinase ${ }^{14-18}$. For this reason, and because penicillins are known to act by interfering with normal cell wall formation ${ }^{17-19}$, the possibility that methicillinresistance might be associated with some alteration in cell wall composition was considered.

Table 1. SCSCEPTIBILITY of Staphylococeus aureus to IYsostaPHiN (L)

\begin{tabular}{|c|c|c|c|c|}
\hline \multicolumn{5}{|c|}{ 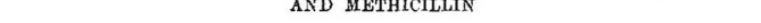 } \\
\hline Strains & $\begin{array}{c}\text { Proportion } \\
\text { Mu }\end{array}$ & $\begin{array}{c}\text { Rate of } \\
\text { Iysis by L, } \\
(\Delta \% \mathrm{~T} / \mathrm{h})\end{array}$ & $\begin{array}{l}\text { Ratio of } \\
\text { rates of lysis, } \\
\text { parent/MR clone }\end{array}$ & $\begin{array}{c}\text { MIC of } \\
\text { methicillin, } \\
(\mu \mathrm{g} / \mathrm{ml} .)\end{array}$ \\
\hline $\begin{array}{l}\text { MR } 1 a \\
M R \\
M R\end{array}$ & $\begin{array}{l}4.2 \times 10^{-5} \\
0.57-0.73\end{array}$ & $\begin{array}{l}45-287 \\
14-34\end{array}$ & $5 \cdot 7-8 \cdot 4$ & $\geqslant 1,600$ \\
\hline MR $2 a$ & $3 \cdot 1 \times 10^{-7}$ & $\begin{array}{l}14-34 \\
99-328\end{array}$ & & $\begin{array}{r}\geqslant 1,600 \\
800\end{array}$ \\
\hline $\operatorname{MR} 2 b$ & 0.57 & $20-83$ & $3 \cdot 7-6 \cdot 3$ & 800 \\
\hline MR $3 a$ & $5 \times 10^{-5}$ & 85 & $3 \cdot 1$ & 800 \\
\hline IR $3 b$ & 0.37 & 27 & & $\geqslant 1,600$ \\
\hline MR $4 a$ & $6 \cdot 3 \times 10^{-5}$ & 56 & & $\geqslant 1,600$ \\
\hline $\operatorname{MR} 4 b$ & 0.37 & 19 & $2 \cdot 9$ & $\geqslant 1,600$ \\
\hline $\operatorname{MR} 5 a$ & $4.5 \times 10^{-6}$ & 72 & 2.8 & 800 \\
\hline MR $5 b$ & $0 \cdot 61$ & 26 & 20 & $\geqslant 1,600$ \\
\hline MR Col. $a$ & 0.06 & 35 & $2 \cdot 5$ & $\geqslant 1,600$ \\
\hline MR Col. $b$ & $0 \cdot 75$ & 14 & & $\geqslant 1,600$ \\
\hline & & $53-165$ & & $6 \cdot 2$ \\
\hline Oxford 167 & 0 & 396 & & $3 \cdot \overline{1}$ \\
\hline
\end{tabular}

MR, Methicillin-resistant, naturally occurring; $a$, clone from antibioticfree agar (parent strain); $b$, clone from agar containing $50 \mu \mathrm{g} / \mathrm{ml}$. of cloxacillin; 0, none detected, that is $<10^{-8}$ of cells in the culture; T, transmission
of light at 500 or $620 \mathrm{~nm} ; M I C=$ minimum inhibiting concentration after $48 \mathrm{~h}$ at $37^{\circ} \mathrm{C}$

Cell walls of naturally occurring MR $S$. aureus were compared with MS cells with respect to amino-acid composition and susceptibility to lysostaphin (supplied by Dr P. Tavormina, Mead Johnson Research Center, Evansvillo, Indiana). The amino-acids of acid hydrolysates of cell walls of populations of predominantly (37-75 per cent) MR cells were found to have essentially the same molar ratios of glutamate, lysine, alanino and glycine as those of MS cells.

Tho predominantly MR cell populations were obtained by cloning three different clinical MR isolates in the presence of $50 \mu \mathrm{g} / \mathrm{ml}$. of cloxacillin. Eight different MS coll populations were studied: two naturally occurring MS strains and six parent strains from which the MS cell populations were cloned and which originally contained only 6 in $10^{2}$ to 3 in $10^{7}$ highly resistant cells, or colony forming units (c.f.u.). The proportion of "highly resistant" c.f.u. was determined by comparing tho total colony count on medium free antibiotic with that on medium containing $50 \mu \mathrm{g} / \mathrm{ml}$. of cloxacillin. The cells were grown for $19 \mathrm{~h}$ at $37^{\circ} \mathrm{C}$ in Difco brain-heart infusion (BHI), washed, disrupted with the MSK mechanical cell homogenizer using $0.1 \mathrm{~mm}$ glass beads ${ }^{20}$. The cell walls were separated by differential centrifugation ${ }^{21,22}$ and hydrolysed with $6 \mathrm{M} \mathrm{HCl}$ at $105^{\circ} \mathrm{C}$. Amino-acids in the hydrolysates were analysed in the Phoenix (Philadelphia) aminoacid analyser.

Rates of lysis of MR and MS strains of $S$. aureus by lysostaphin were compared by observing changes in light transmission at 500 or $620 \mathrm{~nm}$ of intact bacteria suspended

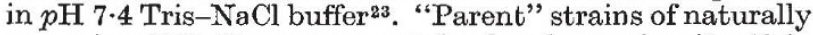
occurring MR $S$. aureus contained only a minority (6 in
$10^{2}-3$ in $10^{7}$ ) of highly resistant c.f.u.; they were lysed by lysostaphin 2.5 to 8.4 times as rapidly as were clones derived from them, which contained 37-75 per cont highly resistant c.f.u. (Table 1). This consistent difference in rate of Iysis was taken as evidence that the cell walls or surfaces of MR cells wero different from those of MS colls because the wall is the substrate for the lysostaphin ${ }^{24,25}$.

The fact that no difference in amino-acid composition of MS and MR cells was detected by the method used suggests that the difference in the walls is not attributablo to different peptide ccmposition. But the data presented could be accounted for by difference in aminoacid sequence, or the presence of some non-peptide component that prevented access of enzyme to its substrate, the glycyl-glycyl bonds ${ }^{24,25}$.

The observed difference in the cell wall or surface could be either the cause of the resistance to methicillin, the result of the resistance mechanism, or a coincidentally linked trait.

Methicillin-resistance per se is not invariably associated with decreased susceptibility to lysostaphin. Two MS strains which were "trained" to methicillin resistance by serial transfers in increasing concentrations of the antibiotic until they grew in $100 \mu \mathrm{g} / \mathrm{ml}$. underwent little or no change in susceptibility to lysostaphin. Similarly, a strain of MS $S$. aureus selected for resistance to lysis by lysostaphin showed no significant change in its resistance to semi-synthetic penicillins.
L. D. SABATH
C. D. LEAF
D. A. Gerstein
M. FINLAND

Thorndike Memorial Laboratory

(Channing Laboratory),

Harvard Medical Unit,

Boston City Hospital

and

Department of Medicine,

Harvard Medical School,

Boston, Massachusetts.

Received September 9, 1969; revised January 6, 1970

${ }^{1}$ Barber, M., in Resistance of Bucteria to the Penicillins, 89 (Churchill, Iondon, 1962).

${ }^{2}$ Chabbert, Y. A., and Paudens, J. G., Ann. Inst. I'usteur, 103, 222 (1962).

${ }^{3}$ Bulger, R. J., lancet, i, 17 (1967).

4 Bastin, R., Worms, R., and Acar, J. F., Pathol. Biol., 15, 1205 (1967).

${ }^{5}$ Churcher, G. M., J. Clin. Pathol., 21, 213 (1968).

${ }^{5}$ Benner, E. J., and Kaysor, F. H., Lancet, ii, 741 (1968),

"Barrett, F. F., McGehee, jun., R. F., and Finland, M., New Engl. J. Med., 279, 441 (1968).

${ }^{8}$ McHenry, M. C., Gavan, T. L., Farmer, R. G., and Evarts, C. M., Cleveland Clinic Quart., 36, 9 (1969).

- Borowski, J., Kamienska, K., and Rutecka, I., Brit. Med. J.,1, 983 (1964).

${ }^{10}$ Dyke, K. G. H., Jevons, P., and Parker, M. T., Lancet, i, 835 (1966).

${ }^{11}$ Chabbert, Y. A., Baudens, J. G., Acar, J. F., and Gerband, G. R., Rev. Franc. Etud. Clin. Biol.,10, 495 (1965).

12 Sabath, J., D., Barrett, F. F., Gerstein, D. A., and Finland, M., Antimicrobial Agents and Chemotherapy-1968, 302 (1969).

${ }^{13}$ Seligman, S. J., Nature, 209, 994 (1966).

" Barber, M., in Drug Resislance in Micro-organisms, 282 (Churchill, London, 1957).

${ }^{15}$ Pollock, M. R., Drug Resistance in Micro-organisms, 78 (Churchill, London, $1957)$.

6 Barber, M. J., Pathol. Bact., 59, 373 (1947).

17 Lederbcrg, J., J. Bact., 73, 144 (1957)

18 Wise, E. M., and Park, J. T., Proc. US Yat. Acad. Sci., 54, 75 (1065).

${ }^{19}$ Tipper, D. J., and Strominger, J. L., Prac. US Nat. Acad. Sci., 54, 1133 (1965).

${ }^{20}$ Bleiweis, A. S., Karakawa, W. W., and Krause, R. M., J. Bact., 88, 1198 (1964)

${ }^{21}$ Salton, M. R. J., The Bacterial Cell Wull, 58 (Elsevier, Amsterdam, 1964).

${ }^{22}$ Nathenson, S. G., and Strominger, J. L., J. Pharm. Exp. Therap., 131, 1 (1961).

${ }^{23}$ Zygmunt, W. A., Harrison, C. F., Browder, I. P., and Tavormina, P. A., Appl. Microbiol., 16, 1174 (1968).

${ }^{4}$ Browder, H. P., Zygmunt, W. A., Young, J. R., and Tavormina, P. A. Biochem. Biophys. Res. Commun., 19, 383 (1965). ${ }^{25}$ Tipper, D. J., and Strominger, J. L., Biochem. Biophys. Res. Commun., 22, 